\title{
RESEARCH NOTE \\ USLE/RUSLE K-factors allocated through a linear mixed model for Uruguayan soils
}

\author{
Andrés Beretta-Blanco ${ }^{1,2}$, Leonidas Carrasco-Letelier ${ }^{3}$ \\ 'Instituto Nacional de Investigación Agropecuaria (INIA), Estación experimental Alberto Boerger INIA La \\ Estanzuela, Laboratorio de aguas y suelos. Colonia, Uruguay. \\ ${ }^{2}$ Universidad de la República, Facultad de Agronomía, Departamento de Suelos y Aguas. Garzón 780, \\ 12900, Montevideo, Uruguay. \\ ${ }^{3}$ Programa de Producción y Sustentabilidad Ambiental, INIA, Estación experimental Alberto Boerger INIA \\ La Estanzuela. Colonia, Uruguay.
}

\begin{abstract}
A. Beretta-Blanco, L. Carrasco-Letelier. 2017. USLE/RUSLE K-factors allocated through a linear mixed model for uruguayan soils. Cien. Inv. Agr. 44(1): 100-112. Soil erosion by rainfall is a process that demands management, both for the prevention of excessive soil erosion and for the protection of the quality of freshwater bodies. Erosion coefficients (K-factors) of the universal soil loss equation (USLE)/revised USLE (RUSLE) model were assigned to 99 mapped Uruguayan soil types at 1:1,000,000 scale. This work developed a linear mixed model (LMM) with 79 soils with assigned $\mathrm{K}$-factors, in which the following variables were considered: soil taxonomy, chemical composition, and parent material. The developed $\mathrm{LMM}$ had an $\mathrm{R}^{2}=0.86$, in which the soil taxonomy $(p<0.0001)$, parent material $(p=0.0174)$, clay $(p=0.0005)$ and sand $(p=0.017)$ contents had significant statistical effects. The prediction capacity of this model was assessed with 10 soils not previously used in development of the LMM with assigned $\mathrm{K}$-factors. The prediction assessment had an $\mathrm{R}^{2}=0.84$ and a mean error of $9.08 \%$ of the mean $\mathrm{K}$-factor value. The LMM developed was used for the allocation of K-factors to soils mapped at a 1:20,000-resolution. Thus, the use of LMM increased the soil area with assigned K-factors from $111,822 \mathrm{~km}^{2}$ (at a scale of 1:1,000,000) to $174,132 \mathrm{~km}^{2}(1: 20,000)$.
\end{abstract}

Keywords: soil classification; parent material; soil texture; soil chemistry

\section{Introduction}

The universal soil loss equation (USLE)/revised USLE (RUSLE) is used to estimate the soil erosion that could occur under defined situations (Clericí and García-Préchac, 2001). This model considers

Received June 06, 2016. Accepted January 17, 2017

Corresponding author: andbere@gmail.com the erodibility of soil as its intrinsic property, named as the K-factor, which means the amount of soil that would be lost per unit of energy of an erosive agent (Puentes and Szogi, 1983). The estimation of this soil property involves measuring soil loss for many years using runoff plot experiments and under standardized conditions. The availability of this experimental evaluation has limited the assessment of K-factors at a large 
scale. As a result, some alternative strategies have been developed for K-factor estimations. These estimation strategies have included measurements of soil loss based on simulation of rainfall or by pedotransfer functions (Durán and GarcíaPrechac, 2007).

Wischmeier et al. (1971) achieved a correlation of 0.95 between the K-factor estimated using a multiple regression model and the K-factor estimated using rainfall simulations on 55 soils from the US Corn Belt. This model required consideration of 24 variables, some of which were not among those used for routine characterization of soils. In Wischmeier and Smith (1978), the number of variables required were reduced to five (Durán and García-Prechac, 2007). The need to reduce the number of variables to minimize costs and required computing capacity was realized in the 1970s. Currently, because of increased access to calculation capacity in modern computers and with greater availability of information, it has become feasible to increase the number of variables and thus increase the estimation capacity of pedotransfer functions.

The pedotransfer functions used to estimate Kfactors were published by Wischmeier and Smith (1978), in which K was dependent on soil texture, organic carbon content, structure, and permeability. Based on this approach, Puentes (1981) estimated the K-factors for $100 \%$ of the soil types present at a mapping scale of 1:1,000,000 using a modification of the pedotransfer formula set by Wischmeier and Smith (1978). This approach represented only 99 of the 173 Uruguayan soil types present at a 1:20,000 scale (Durán and García-Prechac, 2007; MGAP, 2007). Puentes (1981) introduced Henin's structural stability index for encoding the structure (Durán and García-Prechac, 2007), a not-wellknown technique that could be a limitation for the estimation of soil K-factors. Another limitation to the use of the Puentes function (Puentes, 1981) is the determination of very fine sand, which is not a routine analysis at most national laboratories. Puentes (1981) estimated K-factors using the soil properties that originated from soil genesis, parent material and pedological processes. Likewise, the structure coding and soil permeability are conditioned in part by the soil type and geologic material that determine the material for soil genesis (Puentes and Szogi, 1983). In Uruguay, Durán and García-Préchac (2007) conducted runoff plot experiments to estimate the K-factors in three soil types: (1) typical Brunosol (Altamirano et al., 1976a), with parent material classified as silt clay loam (sandy, gravelly)/metamorphic, granite and gneiss rocks; (2) typical Brunosol, with parent material classified as Lodolite/Fray Bentos; and (3) Argisol, with parent material classified as silty clay sediments/metamorphic, granite and gneiss rocks. This strategy could not cover more soil types because of the economic costs and difficulty of implementation. Therefore, the estimations of K-factors were continued using rainfall simulation on other soil types. The results had an acceptable relationship with the estimated values by Puentes (1981); even in soils with high clay content, the estimated K-factor value was higher than the highest K-factor value measured with the rainfall simulator (Durán and GarcíaPrechac, 2007).

Typically, soil surveys contain information about soil physical and chemical composition, soil taxonomic classification, and parent material, but they might lack a coding for structure and information on soil permeability and fine sand content. These variables are required to use the pedotransfer functions of Wischmeier and Smith (1978) or the modification from Puentes (1981). Given the current availability of soils information, including taxonomic classification of soils, their parent materials, and physicochemical characteristics, in addition to the current calculation capabilities (i.e., linear mixed models), it seems feasible to develop a linear mixed model based on soils with assigned K-factors. This model could then be applied to estimate K-factors for soils of unknown K-factor value. In this study, we propose the use of existing soil databases with assigned $\mathrm{K}$-factors to build a linear mixed model that al- 
lows the estimation of $\mathrm{K}$-factors in soils with an unknown value, at resolution scale of 1:20,000.

\section{Materials and methods}

\section{Site and soil description}

The study area is Uruguayan territory $\left(30^{\circ} 11^{\prime} \sim 35^{\circ} 1^{\prime}\right.$ $\mathrm{S}, 53^{\circ} 23^{\prime} \sim 58^{\circ} 26^{\prime} \mathrm{W}$ ) covering $176,215 \mathrm{~km}^{2}$. The study area is $0-513$ meters above sea level, with a range of mean annual rainfall from 700-1200 $\mathrm{mm}$. The climate is temperate and humid without a dry season (Cfa) according to the KöppenGeiger classification (Kottek et al., 2006). The most important climax vegetation is perennial pasture, according to historical records of the natural state of this landscape; the vegetation is characterized by tall grass in most of this territory (Royo Pallares et al., 2005). According to the Soil Atlas of Latin America and the Caribbean, the main soils of Uruguay are Phaeozems, Leptosols, Vertisols, Acrisols, and Luvisols (Gardi et al., 2014). Shallow soils predominate on the basaltic slopes of the northwest while deeper soils of medium-high fertility are dominant in the valleys. Diverse young materials and wavy relief forms are found in the center-northeast, but soils in this region are predominantly shallow to deep with low fertility, although there are some soils of excellent agricultural suitability. In the southeast and east the soils are very shallow, with rocky outcrops; they generally they have low natural fertility and low drought resistance, which developed in broken landforms with steep slopes that have a high risk of erosion. Hills and plains characterize the Atlantic coast; the soils in this region show high resistance to drought and erosion (Gardi et al., 2014).

The national survey of Uruguayan soils uses a country-specific taxonomy (Fig. 1), which highlights that the majority of existing soils in the southcentral and southwest zones have the following characteristics: mineral soils with organic carbon higher than $2 \% \mathrm{w} / \mathrm{w}$; a base saturation higher than $50 \%$ of cation exchange capacity at $\mathrm{pH}=7$; loam, silty loam or silty texture, and moderately deep to deep soils. These soils are classified as typical Brunosols, Luvic Brunosols, Vertisols and Argisols, all of which have developed from sedimentary formations deposited on basement formed with metamorphic, granite and gneiss rocks. In the north-central region of the country, soils are acidic, low in base saturation, contain exchangeable aluminum, and exhibit significant textural differentiation between superficial and subsuperficial horizons. These soils are classified as Acrisols and Luvisols (Altamirano et al., 1976a) that have developed on parent material of sandstone from the Tacuarembó or Rivera regions. These soils occupy an insignificant area. In the northwest, on the basalt hills, there is an extensive area with shallow soils (lower than $30 \mathrm{~cm}$ soil depth) classified as Lithosols, and in the valleys, there are deep soils, classified as Brunosols and Vertisols. In the eastern region, there are plains zones characterized by Planosols and Halomorphic soils with high exchangeable sodium, classified as Solonetz and Solods. On the hills between the midwest and the eastern plains have developed shallow soils classified as Haplic Brunosols, shallow soils classified as Lithosols and underdeveloped soils, lacking or exhibiting underdeveloped subsurface horizons, classified as Inceptisols (Altamirano et al., 1976a). On the riverine and flood zones across the country, small areas of Gleysols, Fluvisols, Luvic Brunosols and Halomorphic soils can be found. This soil diversity was recorded by the soil survey and mapping of soils developed in the 1970s to 1980 . This survey identified 173 soil types that were classified as representative of the Uruguayan territory (MAP/ DSF, 1976; Durán et al., 2005).

\section{Development of a linear mixed model}

A linear mixed model (LMM) was developed with K-factors assigned by Puentes (1981) $\left(\mathrm{K}_{\text {Puentes }}\right)$ to 79 soil types and their physical, chemical, and taxonomic properties (Eq. 1). 


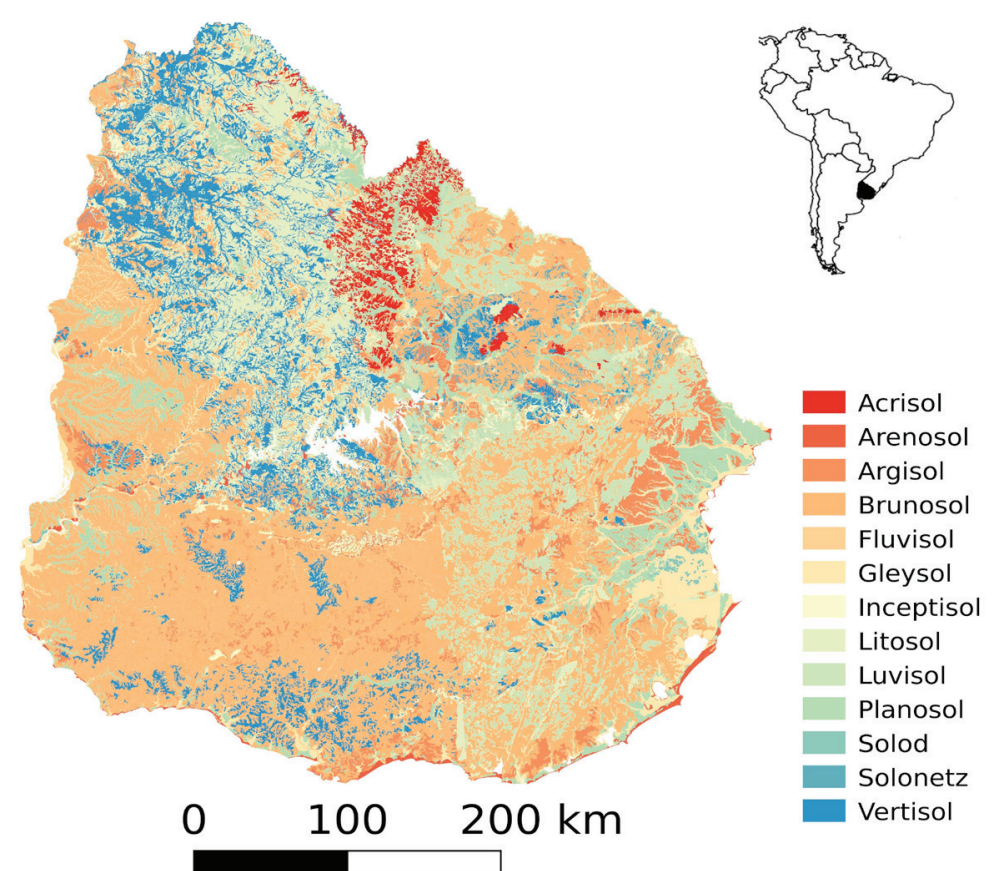

Figure 1. Soil taxonomy system of Uruguay according to Durán and García-Préchac (2007).

$\mathrm{K}=\mathrm{SC}+\mathrm{PM}+\beta \mathrm{Na}+\beta \mathrm{Ca}+\beta \mathrm{Mg}+\beta \mathrm{K}+\beta$ $\Sigma(\mathrm{Ca}+\mathrm{Mg}+\mathrm{Na}+\mathrm{K})+\beta \mathrm{pH}+\beta \mathrm{Corg}+\beta$ sand $+\beta$ clay $+\varepsilon \quad[$ Eq. 1$]$

Equation 1 shows the variables considered in the development of a linear mixed model for K-factor prediction in which the following variables are considered: soil classification (SC); parent material (PM); sodium content of horizon A $(\mathrm{Na})$; calcium content of horizon A $(\mathrm{Ca})$; magnesium content of horizon $\mathrm{A}(\mathrm{Mg})$; potassium content of horizon $\mathrm{A}(\mathrm{K})$; sum of $\mathrm{Ca}, \mathrm{Mg}, \mathrm{Na}$ and $\mathrm{K}$ contents of horizon $\mathrm{A}$; soil $\mathrm{pH}(\mathrm{pH})$; percentage of soil organic carbon content (Corg); percentage of sand content and clay content. Information was retrieved from the soil survey map of Uruguay (Altamirano et al., 1976b). The coefficients and error of linear mixed model are represented as $\beta$ and $\varepsilon$, respectively.

For this analysis, the fixed effects were used as independent variables: (i) soil classification defined at the major group level, and in the case of
Brunosols, to the level of soil type, according to the taxonomy applied by Altamirano et al. (1976a); (ii) parent material, from the information provided by MGAP (2007); (iii) sand and clay content; (iv) organic carbon content; (v) pH; and (vi) exchangeable forms of calcium, magnesium, potassium and sodium using the chemical information published by Molfino (2010) (Table 1). The effects of soil and parent material were introduced as classification variables, while physical and chemical properties were introduced as covariates.

For evaluation of the predictive power of this model, the K-values generated by the linear mixed model (named as $\mathrm{K}_{\mathrm{LMM}}$ ) were compared with $\mathrm{K}_{\text {Puentes }}$ values in 10 soils that were not used for the model development.

The fit of the regression was evaluated through the $\mathrm{R}^{2}$ value. The normal distribution of residues was checked with a Shapiro-Wilk's test. The differences of paired values (predicted values and reference values) were compared 
Table 1. Soil types, physical and chemical characteristics and parent material of soils used in this study.

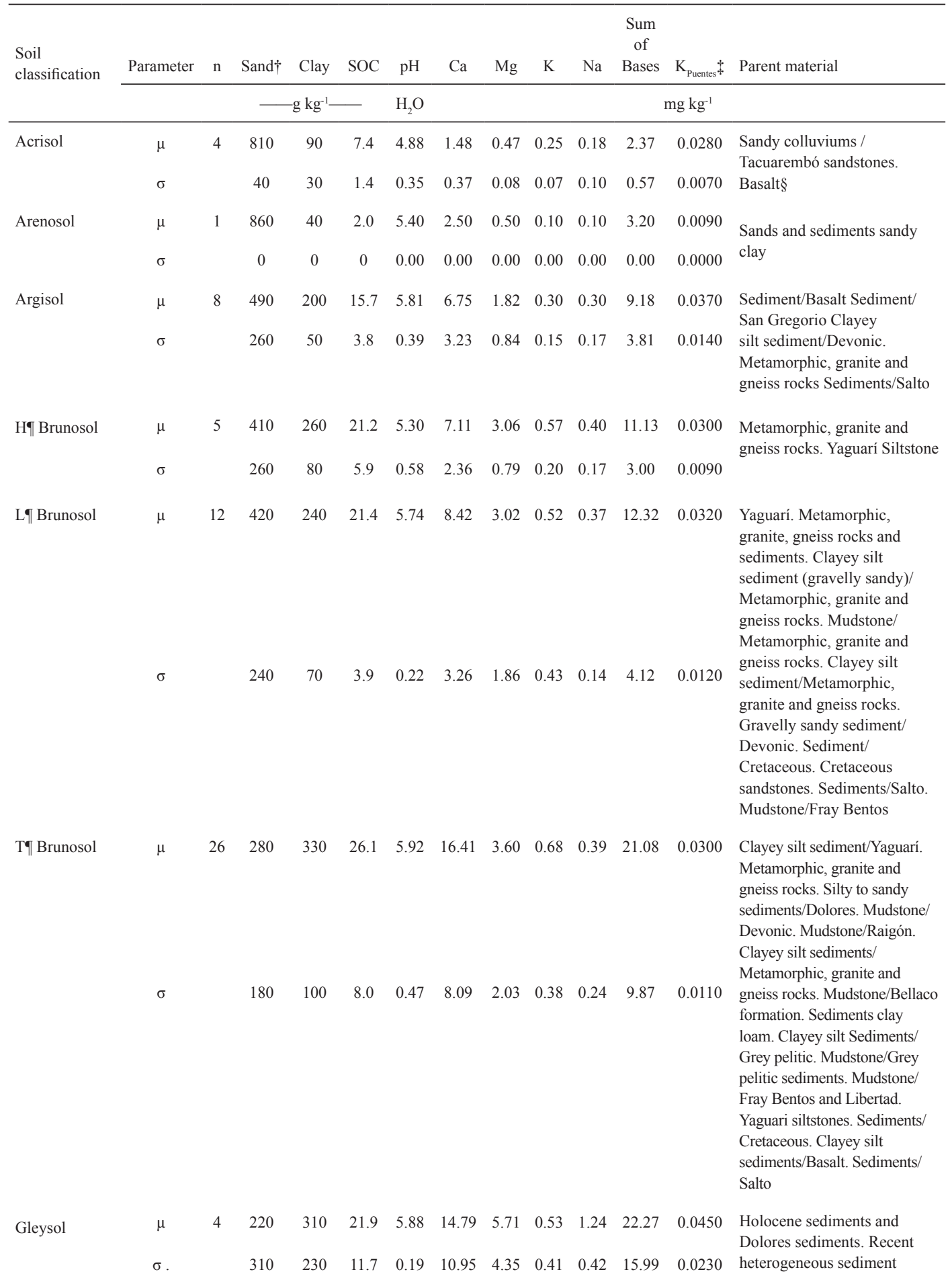




\begin{tabular}{|c|c|c|c|c|c|c|c|c|c|c|c|c|c|}
\hline $\begin{array}{l}\text { Soil } \\
\text { classification }\end{array}$ & Parameter & $\mathrm{n}$ & Sand $\dagger$ & Clay & SOC & $\mathrm{pH}$ & $\mathrm{Ca}$ & $\mathrm{Mg}$ & K & $\mathrm{Na}$ & $\begin{array}{c}\text { Sum } \\
\text { of } \\
\text { Bases }\end{array}$ & $\mathrm{K}_{\text {Puentes }} \stackrel{\hbar}{t}$ & Parent material \\
\hline & & & $\longrightarrow$ & $\mathrm{g} \mathrm{kg}^{-1}$ & - & $\mathrm{H}_{2} \mathrm{O}$ & & & & & & $\mathrm{ng} \mathrm{kg}^{-1}$ & \\
\hline \multirow[t]{2}{*}{ Inceptisol } & $\mu$ & 1 & 680 & 210 & 20.1 & 5.60 & 3.00 & 1.00 & 0.60 & 0.30 & 4.90 & 0.0310 & \multirow[t]{2}{*}{$\begin{array}{l}\text { Metamorphic, granite and } \\
\text { gneiss rocks }\end{array}$} \\
\hline & $\sigma$ & & 0 & 0 & 0 & 0.00 & 0.00 & 0.00 & 0.00 & 0.00 & 0.00 & 0.0000 & \\
\hline \multirow[t]{2}{*}{ Litosol } & $\mu$ & 6 & 500 & 250 & 31.5 & 5.62 & 8.82 & 4.35 & 1.20 & 0.68 & 15.06 & 0.0310 & \multirow{2}{*}{$\begin{array}{l}\text { Siltstone, Yaguarí. Devonic. } \\
\text { Gravelly sandy sediment/ } \\
\text { Devonic. Basalt }\end{array}$} \\
\hline & $\sigma$ & & 270 & 140 & 16.2 & 0.49 & 9.75 & 3.94 & 1.20 & 0.70 & 12.57 & 0.0060 & \\
\hline \multirow[t]{2}{*}{ Luvisol } & $\mu$ & 7 & 680 & 160 & 10.7 & 5.14 & 1.81 & 0.80 & 0.25 & 0.28 & 3.14 & 0.0320 & \multirow{2}{*}{$\begin{array}{l}\text { Sediments/San Gregorio. } \\
\text { Clayey sandy sediments/Tres } \\
\text { Islas. Tacuarembó sandstone. } \\
\text { Metamorphic, granite and } \\
\text { gneiss rocks. Sandy sediments } \\
\text { /Yaguarí }\end{array}$} \\
\hline & $\sigma$ & & 70 & 30 & 3.8 & 0.40 & 0.67 & 0.57 & 0.11 & 0.11 & 1.14 & 0.0120 & \\
\hline \multirow[t]{2}{*}{ Planosol } & $\mu$ & 6 & 310 & 210 & 16.5 & 5.78 & 7.22 & 2.47 & 0.30 & 0.33 & 10.31 & 0.0470 & \multirow{2}{*}{$\begin{array}{l}\text { Sediments/Dolores. Sands } \\
\text { and sediments clayey sandy. } \\
\text { Clayey silt sediment/Basalt. } \\
\text { Sediment/Cretaceous }\end{array}$} \\
\hline & $\sigma$ & & 280 & 90 & 6.8 & 0.26 & 5.36 & 1.23 & 0.19 & 0.10 & 6.58 & 0.0120 & \\
\hline \multirow[t]{2}{*}{ Solod } & $\mu$ & 1 & 210 & 200 & 15.0 & 5.70 & 4.98 & 4.08 & 0.20 & 1.07 & 10.32 & 0.0880 & \multirow[t]{2}{*}{ Dolores } \\
\hline & $\sigma$ & & 0 & 0 & 0 & 0.00 & 0.00 & 0.00 & 0.00 & 0.00 & 0.00 & 0.0000 & \\
\hline \multirow[t]{2}{*}{ Solonetz } & $\mu$ & 2 & 200 & 170 & 19.4 & 7.35 & 6.30 & 4.15 & 0.72 & 5.06 & 16.22 & 0.0740 & \multirow[t]{2}{*}{ Dolores } \\
\hline & $\sigma$ & & 50 & 80 & 14.7 & 0.64 & 3.11 & 0.78 & 0.54 & 1.21 & 4.56 & 0.0040 & \\
\hline \multirow[t]{2}{*}{ Vertisol } & $\mu$ & 6 & 240 & 410 & 31.0 & 6.17 & 27.49 & 7.83 & 0.85 & 0.44 & 36.61 & 0.0180 & \multirow{2}{*}{$\begin{array}{l}\text { Sediments/Basalt. Clayey silt } \\
\text { sediments/Basalt. Mudstone/ } \\
\text { Bellaco. Sediments Libertad/ } \\
\text { Raigón. Sandy sediment/ } \\
\text { Cretaceous }\end{array}$} \\
\hline & $\sigma$ & & 150 & 100 & 5.7 & 0.74 & 8.46 & 3.90 & 0.32 & 0.28 & 12.31 & 0.0060 & \\
\hline
\end{tabular}

†. Physic and chemical data of MGP/DSF (1976).

$\ddagger$ K value assigned by Puentes (1981).

$\S$ Parent material nomenclature is a simplification of names used in MGAP (2007).

I $\mathrm{H}$ is haplic; $\mathrm{T}$ is typical.

with Student's test or with Wilcoxon's signed rank test, if there was no normal distribution (Zar, 2014). All statistical tests were performed using the InfoStat/P software (Di Rienzo et al., 2014), supplemented with statistical package $R$ (R Core Team, 2016).

\section{Development of mapping $K$-factors}

The information modified by Molfino (2010) of the soil productivity map named the CONEAT classification system (map at 1:20,000 scale) was used in the development of mapping K-factors, in which a soil type profile was assigned to each CONEAT soil group. A $\mathrm{K}_{\text {Puentes }}$ value was then assigned to each soil group. For 76 soil types without $\mathrm{K}_{\text {Puentes }}$ values, a $\mathrm{K}_{\text {LMM }}$ value was assigned based on the LMM prediction. The result was transferred to a geographical information system using QGIS software (QGIS Development Team, 2014), creating a vector layer software with the information generated.

All K-values were expressed in compatible SI units, i.e., in ( $\mathrm{t}$ ha h)(ha $\mathrm{MJ} \mathrm{mm})^{-1}$. 


\section{Results}

\section{Linear mixed model}

The proposed adjusted linear mixed model (Eq. 2) satisfactorily explained 83 percent of variations of $\mathrm{K}_{\text {Puentes }}\left(\mathrm{R}^{2}=0.83\right.$; $\mathrm{AIC}=-132.32$; $\mathrm{BIC}=-4.37$; $\operatorname{LogLik}=120.16$; Fig. 2; Table 2). The differences between $\mathrm{K}_{\mathrm{LMM}}$ and $\mathrm{K}_{\text {Puentes }}$ did not follow a normal distribution ( $\mathrm{W}=0.936$, $\mathrm{p}=0.002$ ). Therefore, these were analyzed with a Wilcoxon signed rank test with continuity correction. This analysis showed that $\mathrm{K}_{\mathrm{LMM}}$ average values did not differ from $\mathrm{K}_{\text {Puentes }}$ average values $(\mathrm{V}=805, \mathrm{p}=0.699)$. In the $\mathrm{LMM}$ developed, the following variables showed significant statistical effect: (a) soil classification $(\mathrm{df}=13, \mathrm{p}<0.0001)$; (b) parent material $(\mathrm{df}=36$; $\mathrm{p}=0.0174)$; (c) clay content $(\mathrm{df}=1 ; \mathrm{p}=0.0005)$; and (d) sand content ( $\mathrm{df}=1, \mathrm{p}=0.017)$. A statistically significant trend was found for soil organic carbon $(\mathrm{df}=1 ; \mathrm{p}=0.0776)$. The other variables $(\mathrm{Na}, \mathrm{Ca}, \mathrm{Mg}, \mathrm{K}$, sum of cations, $\mathrm{pH}$ ) in the initially proposed model (Eq. 1) did not show any significant effects.

$\mathrm{K}=\mathrm{SC}+\mathrm{PM}+\beta \operatorname{Corg}+\beta$ sand $+\beta$ clay $+\varepsilon[$ Eq. 2$]$

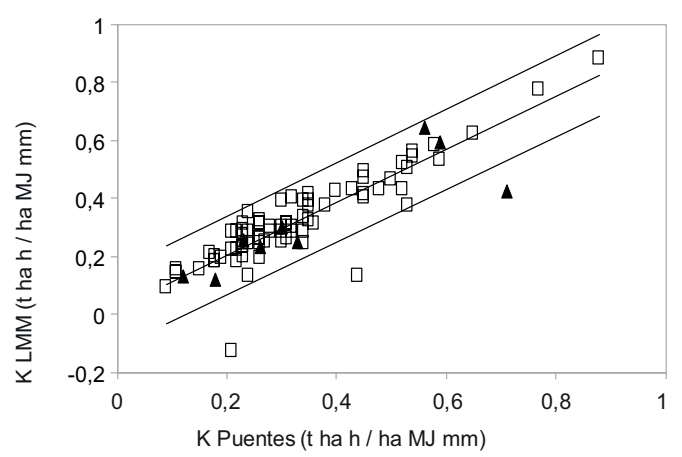

Figure 2. K-factor pairs of data from Puentes (1981) and LMM estimation (shown as open boxes). The line ( $\mathrm{y}=0.978$ $\mathrm{x} ; \mathrm{R}^{2}=0.86, n=79$ ) corresponds to the linear relationship between $\mathrm{K}_{\text {Puentes }}$ and $\mathrm{K}_{\mathrm{LMM}}$. Segmented lines correspond to prediction intervals. Black triangles are Puentes's K-factor data not used in the model development.
In the estimation of K-factor values for the 10 soils not used in the model fit (Table 3), the relationship between $\mathrm{K}_{\text {Puentes }}$ values and $\mathrm{K}_{\mathrm{LMM}}$ values was satisfactory (Fig. 2). The regression coefficient did not differ from one and the average error was -0.0034 ( $\mathrm{t}$ ha $\mathrm{h}$ )(ha $\mathrm{MJ} \mathrm{mm})^{-1}$, equivalent to $9.08 \%$ of the average K-factor value of these 10 soils. The Shapiro-Wilk normality test did not show a normal distribution of errors ( $\mathrm{W}=0.79$; $p$ 0.010; Fig. 3), probably by an outlier from an underestimation of -0.0289 ( $t$ ha $h$ )(ha MJ $\mathrm{mm})^{-1}$ with the Solonetz soil on loamy to sandy sediment on the Dolores geological formation, which was the soil with the highest $\mathrm{K}_{\text {Puentes }}$ value. However, the Wilcoxon signed rank test of these errors did not show significant differences with a mean equal to zero $(\mathrm{V}=18, \mathrm{p}=0.375)$.

\section{Developing a map of $K$-factors}

Based on the developed LMM, a $\mathrm{K}_{\mathrm{LMM}}$ value was assigned to 76 soils (Fig. 4) without $\mathrm{K}_{\text {Puentes }}$ values; based on the CONEAT map modified by Molfino (2010), it was possible to expand coverage with $\mathrm{K}$-factor values from $111,822 \mathrm{~km}^{2}$ to $174,132 \mathrm{~km}^{2}$ (Fig. 4).

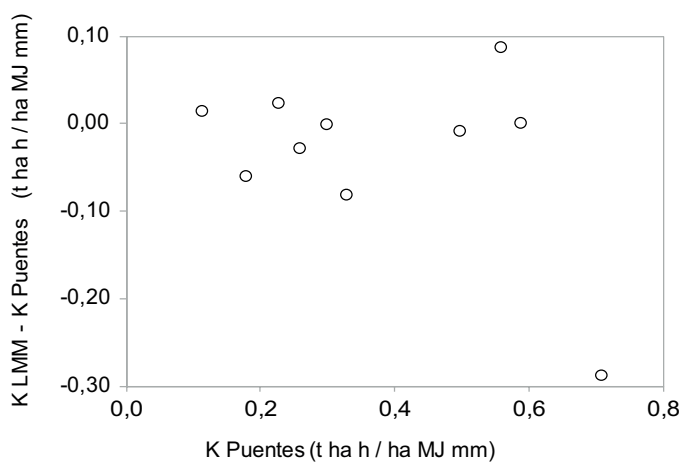

Figure 3. Difference between estimated K-factor and measured K-factor for 10 soils not used in the model development. 
Table 2. Effects and coefficients defined by the linear mixed model for estimation of soil K-factors.

\begin{tabular}{|c|c|c|c|}
\hline Effect $\dagger$ & coefficient & Effect $\dagger$ & coefficient \\
\hline (Intercept) & 0.60644 & Mudstone/Raigón & -0.24114 \\
\hline Arenosol & -0.25767 & Mudstone/Pelitic sediments Grey Pelitic & -0.19819 \\
\hline Argisol & 0.32611 & Salto & -0.42678 \\
\hline Brunosol Haplic & 0.20426 & Clay-loam sediments & -0.32759 \\
\hline Brunosol Luvic & 0.32263 & Gravelly sandy sediment/Devonic & -0.19808 \\
\hline Brunosol Typical & 0.40553 & Clayey silt sediment (gravelly sandy) & -0.18211 \\
\hline Gleysol & 0.23828 & Clayey silt sediment/Basalt & -0.00617 \\
\hline Inceptisol & 0.2882 & $\begin{array}{l}\text { Clayey silt sediment/Metamorphic, granite and gneiss } \\
\text { rocks }\end{array}$ & -0.14615 \\
\hline Litosol & 0.29868 & Clayey silt sediment/Devonic & -0.29865 \\
\hline Luvisol & 0.0521 & Clayey silt sediment/Grey Pelitic & -0.18021 \\
\hline Planosol & 0.25659 & Clayey silt sediment/Yaguarí & -0.15941 \\
\hline Solod & 0.59512 & Sediment/Basalt & -0.0907 \\
\hline Solonetz & 0.50278 & Sediment/Cretaceous & -0.23301 \\
\hline Vertisol & 0.26864 & Sediment/San Gregorio & -0.01596 \\
\hline Cretaceous sandstones & -0.12259 & Sandy sediment/Cretaceous & -0.16328 \\
\hline Tacuarembó sandstones & 0.0009 & Clayey silt sediment/Tres Islas & 0.14773 \\
\hline Basalt & 0.05853 & Sandy sediment/Yaguarí & 0.01739 \\
\hline $\begin{array}{l}\text { Sandy colluvium / Tacuarembó } \\
\text { sandstones }\end{array}$ & -0.05348 & Recent heterogeneous sediment & 0.23308 \\
\hline Intrusive igneous rocks & -0.1053 & Sediment Libertad/Raigón & -0.06345 \\
\hline Intrusive igneous rocks and sediments & -0.04014 & Silty to sandy sediments/Dolores & -0.38864 \\
\hline Devonic & -0.23051 & Sediments/Dolores & 0.03372 \\
\hline Libertad formation & -0.13168 & Sediments/Salto & -0.22534 \\
\hline Yaguarí Siltstone & 0.0037 & Yaguarí & -0.34131 \\
\hline Siltstone/intrusive igneous rocks & 0.01549 & Sand $(\%)$ & -0.00245 \\
\hline Siltstone/Bellaco & -0.17953 & Clay $(\%)$ & -0.00904 \\
\hline Siltstone/Devonic & -0.10626 & Soil organic carbon $(\%)$ & -0.05965 \\
\hline Siltstone/Fray Bentos & -0.23065 & & \\
\hline
\end{tabular}

$\dagger$ Parent Material coded in a simplified form of those used in MGAP (2007).

Table 3. Physical, chemical, taxonomic and parent material of 10 soils used to validate the estimation of soil K-factors.

\begin{tabular}{|c|c|c|c|c|c|c|}
\hline Sand & Clay & $\mathrm{SOC}$ & $\mathrm{pH}$ & $\begin{array}{c}\text { Soil } \\
\text { classification }\end{array}$ & Parent Material $\dagger$ & $\mathrm{K}_{\mathrm{LMM}}$ \\
\hline & $-\mathrm{g} \mathrm{kg}^{-1}-$ & & $\mathrm{H}_{2} \mathrm{O}$ & & & (t ha h ha ${ }^{-1} \mathrm{MJ}^{-1} \mathrm{~mm}^{-1}$ ) \\
\hline 110 & 220 & 13.8 & 6.4 & Argisol & $\begin{array}{l}\text { Mudstone/Metamorphic, granite and } \\
\text { gneiss rocks }\end{array}$ & 0.0601 \\
\hline 750 & 210 & 13.2 & 6.0 & Argisol & Sediment/Cretaceous & 0.0304 \\
\hline 600 & 210 & 19.4 & 5.9 & $\mathrm{H} \ddagger$ Brunosol & Metamorphic, granite and gneiss rocks & 0.0263 \\
\hline 90 & 310 & 30.2 & 5.7 & $\mathrm{H} \ddagger$ Brunosol & Metamorphic, granite and gneiss rocks & 0.0278 \\
\hline 80 & 510 & 29.5 & 6.3 & $\mathrm{~T} \ddagger$ Brunosol & Mudstone/Fray Bentos & 0.0118 \\
\hline 360 & 280 & 18.4 & 5.2 & $\mathrm{~T} \$$ Brunosol & Clay-loam sediment & 0.0240 \\
\hline 130 & 410 & 39.8 & 6.2 & T\$Brunosol & Clay-loam sediment/Basalt & 0.0334 \\
\hline 150 & 190 & 30.3 & 5.9 & Gleysol & Sediment/Dolores & 0.0500 \\
\hline 750 & 150 & 9.6 & 4.6 & Luvisol & Sandy sedimentos/Yaguarí & 0.0300 \\
\hline 170 & 230 & 9.0 & 7.8 & Solonetz & Silty to Sandy Sediment/Dolores & 0.0710 \\
\hline
\end{tabular}

$\dagger$ Parent material coded in a simplified form of those used in MGAP (2007).

$\ddagger \mathrm{H}$ is haplic; $\mathrm{T}$ is typical. 


\section{Discussion}

Our developed LMM opens an option to apply the USLE/RUSLE model to the soils that currently do not have an assigned K-factor. In this framework, the $\mathrm{K}_{\mathrm{LMM}}$ values could be useful for the management of soil erosion risk in the same way that the $\mathrm{K}_{\text {Puentes }}$ values are used at a lowresolution scale $(1: 1,000,000)$. The $\mathrm{K}_{\mathrm{LMM}}$ group values allowed a $56 \%$ increase in coverage of the allocation of K-factors (Fig. 4) at a scale of 1:20,000. This contribution will allow enhanced implementation of soil erosion models based on USLE and/or RUSLE (García-Préchac and Durán, 1999; Clericí and García-Préchac, 2001; Durán and García-Prechac, 2007; Hill et al., 2008) or through the combination of land cover and soil information through a GIS (Kouli et al., 2008; Bulut et al., 2012; Demirci and Karaburun, 2012; Avanzi et al., 2013). This is necessary work for soil erosion prevention through soil conservation policies (Kuhlman et al., 2010), such as those suggested by Prager et al. (2011), that Uruguay has implemented at a national scale since 2012 (MGAP, 2012).

Moreover, the current information about soil's $\mathrm{K}$-factors is a limitation used to obtain a soilrisk assessment based in USLE/RUSLE and GIS similar to other researchers (Kouli et al., 2008; Demirci and Karaburun, 2012). A goal that will become necessary is to identify what are the watersheds with the highest potential for soil erosion due to agriculture expansion and intensification driven by the soybean crops in the last 20 years. This is a problem shared with neighboring regions (Entre Ríos Province, Argentine; Rio Grande do Sul State, Brazil). Nevertheless, although both regions have soil maps at 1:100,000 scale (Hellnvig Zarnott, 2011; INTA, 2015), only Entre Ríos has a calibrated USLE model. Therefore, only Entre Ríos could use our strategy for K-factor allocation.

In relation to the structure of our LMM, soil taxonomy and parent material have a significant effect on the LMM, which agrees not only with Puentes's works (Puentes, 1981; Puentes and Szogi, 1983), as expected, but also with Yusof et al. (2012) and Colombo et al. (2010), in the sense that their information related to the parent material and soil type in the estimation of K-factors. In addition, the strategy used in this study was consistent with the strategy proposed by Puentes (1981) because the variables sand, clay and organic carbon contents were used by Puentes (1981) in his estimation of K-factors, so it was also expected that these variables would have a significant effect on the LMM developed.

In the equation used by Puentes (1981) to estimate K-factors, the encoding of permeability and structure might change by one unit because of differences in the interpretation of the morphological characteristics of the soil, which would generate differences in the calculated K-factor. The change in one unit of structure coding could cause a difference of 0.0043 (t ha h)(ha MJ mm) 1 , while the change of one unit of permeability coding could cause a difference of 0.0033 (t ha h)(ha $\mathrm{MJ} \mathrm{mm})^{-1}$. If we consider these findings in calculating the coefficient $\mathrm{K}$ could have an error of 0.0076 ( $\mathrm{t}$ ha $\mathrm{h}$ )(ha MJ $\mathrm{mm})^{-1}$, because of coding differences in a structure unit and in a permeability unit, three of the 10 soils not used in the LMM adjustment, and 14 of the 79 soils used in the model adjustment would have an unacceptable error $\left(>0.0076 \mathrm{t}\right.$ ha h ha $\mathrm{MJ}^{-1}$ $\left.\mathrm{mm}^{-1}\right)$. In the validation data set, two of these estimation errors would not change the erosion risk management, because this risk would remain high regardless of the $\mathrm{K}$-factor value used. The third observed error was a $\mathrm{K}_{\text {LMM }}$ value of 0.0252 ( $\mathrm{t} \mathrm{ha} \mathrm{h}$ )(ha MJ mm) $)^{-1}$ instead of a $\mathrm{K}_{\text {Puentes }}$ value of 0.0333 ( $\mathrm{t} \mathrm{ha} \mathrm{h}$ )(ha MJ mm) ${ }^{-1}$, which could generate a significant change in erosion risk management. Therefore, we believe that the error linked to LMM results would be significant in a minority of cases. Elimination of the greatest error of estimation from the validation value set would change the average $\mathrm{K}_{\text {LMM }}$ value by 0.006 $\mathrm{Mg} \mathrm{J}^{-1}$ compared with the average $\mathrm{K}_{\text {Puentes }}$ value. 

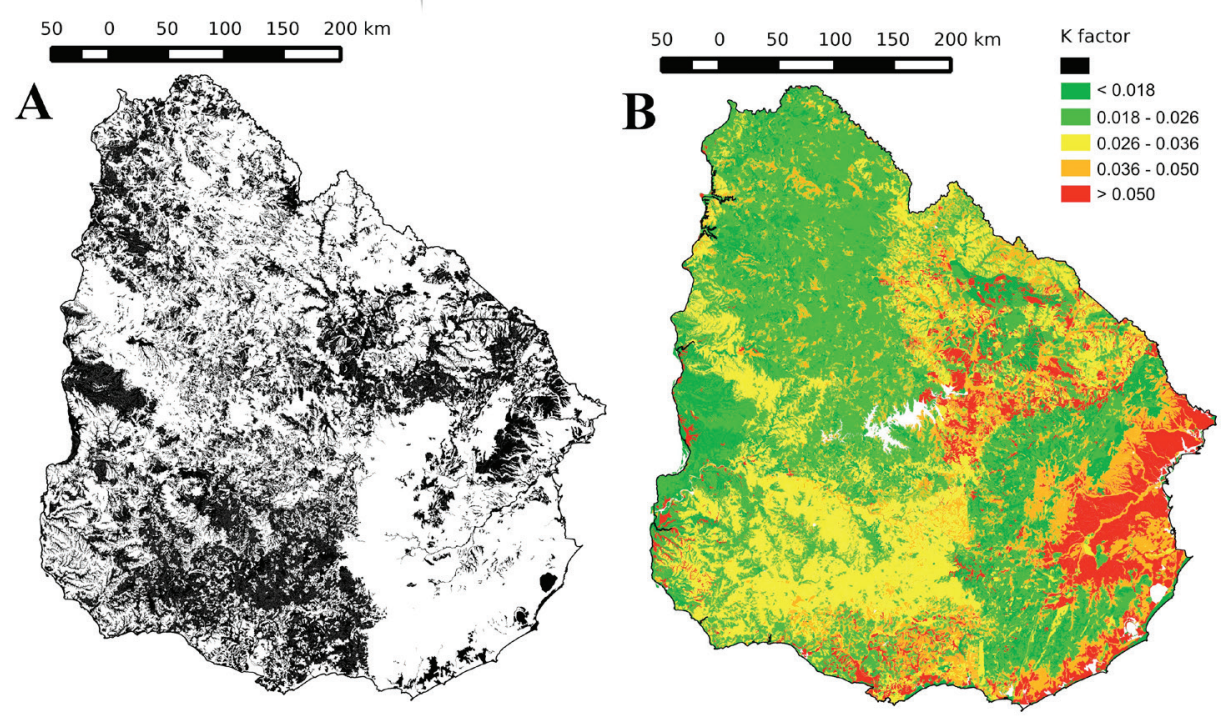

Figure 4. K-factors of soils at 1:20,000 scale. (A) Soils with assigned K-factor by Puentes (1981) shown as gray zones, and soils without K-factor shown as black zones; and (B) $\mathrm{K}_{\mathrm{LMM}}$-factor for each soil. K-values expressed in ( $\mathrm{t} \mathrm{ha} \mathrm{h} \mathrm{ha}{ }^{-1} \mathrm{MJ}^{-1} \mathrm{~mm}^{-1}$ ).

For the K-factor estimations for the Algorta soil unit, Califra et al. (2007) reported variations of 0.007 (t ha h)(ha MJ mm) $)^{-1}$ in Planosols, 0.002 (t ha h)(ha MJ mm) $)^{-1}$ in Argisols, and 0.011 (t ha h)(ha MJ mm $)^{-1}$ in Brunosols because of differences in the physical and chemical composition of soils regardless of variations in permeability and/or infiltration codes. The estimations of $\mathrm{Pu}$ entes (1981) were on average 0.0024 ( $t$ ha $h$ )(ha $\mathrm{MJ} \mathrm{mm})^{-1}$ higher than $\mathrm{K}$ measurements with the rainfall simulator, with differences of up to 0.009 (t ha h)(ha MJ mm) $)^{-1}$ observed (García-Prechac and Durán, 2001). In the same manner, in Puentes's estimation was evident an overestimation of Kfactors of soils with high clay content (Durán and García-Prechac, 2007), perhaps as a consequence of Puentes's modification (Puentes, 1981) of the Wischmeier and Smith (1978) procedure for the $\mathrm{K}$-factor prediction in soils with organic matter content up to $6 \%$ (Durán and García-Prechac, 2007). On the other hand, it is possible that the use of Puentes's (1981) function retains the errors from the use of the function instead of the nomographs of Wischmeier and Smith (1978) and that this bias prevents an adequate estimation in soil with high silt content, low erodibility, or with rock fragments on soil surface, as mentioned in Auerswald et al. (2014). Because the linear mixed model in this study was developed from the base of $\mathrm{K}_{\text {Puentes }}$ values, it must have similar errors in estimation to those in Puentes (1981).

Hydric soil erosion depends on several factors, but in general terms it can be assumed that in soils with $\mathrm{K}$-factor values less than 0.018 ( $\mathrm{t}$ ha $\mathrm{h}$ )(ha MJ $\mathrm{mm})^{-1}\left(28,775 \mathrm{~km}^{2}\right)$, extensive farming could be developed without the need to implement significant management measures for risk-erosion control. In these soils, it would be necessary to prioritize stubble management to optimize soil protection from the direct impact of rain for the longest time. This strategy becomes more important in soils with high K-factor values, where it is necessary to introduce long periods of crops or perennial pastures. In soils with $\mathrm{K}$-factor values between 0.018 and 0.026 (t ha h)(ha MJ mm) ${ }^{-1}\left(57,502 \mathrm{~km}^{2}\right)$, agricultural production of annual crops could be implemented but with biannual crop rotations. For soils with K-factor values between 0.026 and 0.036 (t ha h)(ha MJ mm) $)^{-1}\left(36,688 \mathrm{~km}^{2}\right)$, perennial species should be planted most of the time and less time should be devoted to annual crops. In soils 
with K-factor values between 0.036 and 0.050 (t ha $\mathrm{h})$ (ha MJ mm) $)^{-1}\left(28,456 \mathrm{~km}^{2}\right)$, in addition to prioritizing the cultivation of perennial species, support practices should be implemented (terraces or pasted strips) that reduce surface runoff. In soils with $\mathrm{K}$-factor values greater than 0.050 ( $\mathrm{t} \mathrm{ha} \mathrm{h}$ )(ha $\mathrm{MJ} \mathrm{mm})^{-1}\left(22,713 \mathrm{~km}^{2}\right)$, annual crop production would not be advisable, and these soils should be used for grazing or forest plantations. A clear exception is eastern soils; their K-factor values are high, but with their low slope, the water erosion risk is low, and the rice crops do not promote soil loss by erosion.

The main conclusions are as follows. The developed LMM can estimate the K-factor for Uruguayan soils. This strategy allows the allocation of a $\mathrm{K}$ value $\left(\mathrm{K}_{\mathrm{LMM}}\right)$ to soils that currently do not have a K-factor value and to which, therefore, the USLE/RUSLE-calibrated model cannot be applied. This strategy allowed the development of a K-factor map with a 1:20,000 scale for Uruguay.

\section{Acknowledgements}

This study was funded by the National Agricultural Research Institute (INIA) with its project INIA SA27 "National System for Identification of Agriculture Land Use with High Impact on Freshwater Quality."

\title{
Resumen
}

\begin{abstract}
A. Beretta-Blanco, L. Carrasco-Letelier. 2016. Factores $K$ de USLE/RUSLE asignados a través de un modelo lineal mixto a suelos de Uruguay. Cien. Inv. Agr. 44(1): 100-112. La erosión del suelo es un proceso que demanda gestión, tanto para la prevención de excesos de erosión como por la protección de la calidad de los cuerpos de agua dulce. Los coeficientes de erosión (factores K) del modelo (USLE)/USLE revisado (RUSLE) de la ecuación universal de pérdida de suelos fueron asignados a 99 tipos de suelos uruguayos cartografiados a un escala de 1:1,000,000. Este trabajo desarrollo un modelo linear mixto (LMM) con 79 suelos con factores $\mathrm{K}$ asignados, en los cuales se consideraron las siguientes variables: taxonomía del suelos, composición química y material parental. El LMM desarrollado tuvo un $\mathrm{R}^{2}=0.86$, donde la taxonomía de suelos $(p<0.0001)$, el material parental $(p=0.0174)$, los contenido de arcilla $(p=0.0005)$ y arena $(p=0.017)$ tuvieron efectos estadísticos significativos. La capacidad de predicción de este modelo fue evaluada con 10 suelos con factores $\mathrm{K}$ asignados, que no se usaron previamente en el desarrollo del LMM. La evaluación de la predicción tuvo un $\mathrm{R}^{2}=0.84$ y un error medio de $9.08 \%$ del valor medio del factor K. El LMM desarrollado fue utilizado para la asignación de los factores K para suelos cartografiados con una resolución de 1:20,000. De esta manera, la aplicación del LMM incrementó el área de suelo con factores $\mathrm{K}$ asignados desde $111,822 \mathrm{~km}^{2}$ (con una escala de 1:1,000,000) a 174,132 $\mathrm{km}^{2}$ (con una escala de 1:20,000).
\end{abstract}

Palabras clave: Clasificación de suelos, material parental, química de suelos, textura del suelos. 


\section{References}

Altamirano, A., H. Da Silva, A. Durán, A. Echevarría, D. Panario, and R. Puentes. 1976a. Carta de Reconocimiento de Suelos del Uruguay. Tomo I: Clasificación de suelos. Dirección de Suelos y Fertilizantes, Ministerio de Agricultura y Pesca, Montevideo, Uruguay.

Altamirano, A., H. Da Silva, A. Durán, A. Echevarría, D. Panario, and R. Puentes. 1976 b. Carta de Reconocimiento de Suelos del Uruguay. Tomo III: Descripción de las unidades de suelos. Dirección de Suelos y Fertilizantes, Ministerio de Agricultura y Pesca, Montevideo, Uruguay.

Auerswald, K., P. Fiener, W. Martin, and D. Elhaus. 2014. Use and misuse of the $\mathrm{K}$ factor equation in soil erosion modeling: An alternative equation for determining USLE nomograph soil erodibility values. Catena 118: 220-225.

Avanzi, J.C., M.L.N. Silva, N. Curi, L.D. Norton, S. Beskow, and S.G. Martins. 2013. Spatial distribution of water erosion risk in a watershed with eucalyptus and Atlantic Forest. Ciênc. E Agrotecnologia 37(5): 427-434.

Bulut, G.G., M. Cal, C. Richardson, and J. Gallegos. 2012. A GIS-Based Soil Erosion Risk Map for New Mexico. p. 3754-3763. In World Environmental and Water Resources Congress 2012. American Society of Civil Engineers.

Califra, A., A. Ruiz, F. Alliaume, and A. Durán. 2007. Contribución al estudio de los suelos “Algorta." Agrociencia 11(1): 35-46.

Clericí, C., and F. García-Préchac. 2001. Aplicaciones del modelo USLE/RUSLE para estimar pérdidas de suelo por erosión en Uruguay y la región sur de la cuenca del Río de la Plata. Agrociencia $\mathrm{V}:$ 92-103.

Colombo, C., G. Palumbo, P.P.C. Aucelli, A. De Angelis, and C.M. Rosskopf. 2010. Relationships between soil properties, erodibility and hillslope features in Central Apennines, Southern Italy. p. 117-120. In Brisbane, Australia.

Demirci, A., and A. Karaburun. 2012. Estimation of soil erosion using RUSLE in a GIS framework: a case study in the Buyukcekmece Lake water- shed, northwest Turkey. Environ. Earth Sci. 66 (3): 903-913.

Di Rienzo, J.A., F. Casanoves, M.G. Balzarini, L. Gonzalez, M. Tablada, and W. Robledo. 2014. InfoStat, 2014. Grupo InfoStat, FCA, Universidad Nacional de Córdoba, Argentine.

Durán, A., A. Califra, J.H. Molfino, and W. Lynn. 2005. Keys to soil taxonomy for Uruguay. United States Department of Agriculture, Natural Resources Conservation Service. Washington, D.C., USA.

Durán, A., and F. García-Prechac. 2007. Suelos del Uruguay. Origen, clasificación, manejo y conservación. Hemisferio Sur, Montevideo, Uruguay.

García-Préchac, F., and A. Durán. 1999. Estimating soil productivity loss due to erosion in Uruguay in terms of beef and wool production on natural pastures. p. 24-29.

García-Prechac, F., and A. Durán. 2001. Estimating Soil Productivity Loss Due to Erosion in Uruguay in Terms of Beef and Wool Production on Natural Pastures. p. 40-45. In Sustaining the Global Farm. D.E. Stott, R.H. Mohtar and G.C. Steinhardt (eds), Purdue University and the USDA-ARS, National Soil Erosion Research Laboratory, USA.

Gardi, C., M. Angelini, S. Barceló, J. Comerma, C. Cruz Gaistardo, A. Encina Rojas, A. Jones, P. Krasilnikov, M.L. Mendonça Santos Brefin, L. Montanarella, O. Muñiz Ugarte, P. Schad, M.I. Vara Rodríguez, and R. Vargas. 2014. Atlas de suelo de América Latina y el Caribe. Comisión Europea - Oficina de Publicaciones de la Unión Europea, L-2995, Luxembourg.

Hellnvig Zarnott, D. 2011. Optimização da alocação de áreas florestadas visando a conservação do solo e da água em propriedades familiares. M.Sc. Thesis, Universidad Federal de Pelotas, Pelotas, Brazil.

Hill, M., F. García Prechac, J. Terra, and J. Sawchik. 2008. Incorporación del efecto del contenido de agua en el suelo en el modelo USLE/RUSLE para estimar erosión en Uruguay. Agrociencia 12(2): 57-67.

INTA, (Instituto Nacional de Tecnología Agropecuaria). 2015. Cartas de Suelos de Entre Ríos, GeoINTA. Cartas Suelos Entre Ríos. Available at 
http://geointa.inta.gov.ar/web/index.php/cartasde-suelos-de-entre-rios/ (verified 2 June 2015).

Kottek, M., J. Grieser, C. Beck, B. Rudolf, and F. Rubel. 2006. World Map of the Köppen-Geiger climate classification updated. Meteorol. Z. 15(3): 259-263.

Kouli, M., P. Soupios, and F. Vallianatos. 2008. Soil erosion prediction using the Revised Universal Soil Loss Equation (RUSLE) in a GIS framework, Chania, Northwestern Crete, Greece. Environ. Geol. 57(3): 483-497.

Kuhlman, T., S. Reinhard, and A. Gaaff. 2010. Estimating the costs and benefits of soil conservation in Europe. Land Use Policy 27(1): 22-32.

MAP/DSF. 1976. Carta de Reconocimiento de Suelos del Uruguay. Tomo III Apéndice- parte I y parte II. Descripciones, datos físicos y químicos de los suelos dominantes. Dirección de Suelos y Fertilizantes. Ministerio de Agricultura y Pesca, Montevideo, Uruguay.

MGAP. 2007. Compendio Actualizado de información Suelos de Uruguay. Dirección de Recursos Naturales Renovables. División de Suelos y Aguas, Ministerio de Ganadería, Agricultura y Pesca, Montevideo, Uruguay.

MGAP. 2012. Planes de uso y manejos de suelos. Ministerio de Ganadería, Agricultura y Pesca, Montevideo, Uruguay. Available at http://www. mgap.gub.uy/unidad-ejecutora/direccion-general-de-recursos-naturales/suelos/planes-deuso-y-manejo-de-suelos (verified 5 November 2015).

Molfino, J.H. 2010. Principales características morfológicas y químicas del terreno de los grupos CONEAT, Unidad de Agroclima y Sistemas de Información, INIA, Uruguay.

Prager, K., K. Helming, and K. Hagedorn. 2011. The challenge of developing effective soil conservation policies. Land Degrad. Dev. 22(1): 1-4.
Puentes, R. 1981. A framework for the use of the universal soil loss equation in Uruguay. Master's thesis, Texas A\&M University, Texas, USA.

Puentes, R., and A. Szogi. 1983. Manual para la utilización de la ecuación universal de pérdida de suelo en Uruguay. Departamento de Suelos, Ministerio de Agricultura y Pesca, Montevideo, Uruguay.

QGIS Development Team. 2014. QGIS Geographic Information System. Open Source Geospatial Foundation Project.

R Core Team. 2016. R: a language and environment for statistical computing. R fundation for statistical computing, Vienna.

Royo Pallares, O., E.J. Berretta, and G.E. Maraschin. 2005. Chapter 5: The South American Campos Ecosystem. p. 171-220. In Grasslands of the World. Plant Production and Protection Series. FAO (Food and Agriculture Organization of the United Nations), Rome, Italy.

Wischmeier, W.H., C.B. Johnson, and Cross, B.V. 1971. Soil erodibility nomograph for farmland and construction sites. J. Soil Water Conserv. 26: 189-193.

Wischmeier, W.H., and D.D. Smith. 1978. Predicting rainfall erosion lossess. A guide to conservation planning. Superintendent of Documents, U.S. Government Printing Office. Science and Education Administration, United States Department of Agriculture \& Purdue Agricultural Experiment Station, Washington, D.C. 20402.

Yusof, M.F., H.M. Azamathulla, and R. Abdullah. 2012. Prediction of soil erodibility factor for Peninsular Malaysia soil series using ANN. Neural Comput. Appl. 24(2): 383-389.

Zar, J.H. 2014. Biostatistical Analysis: Pearson New International Edition. 5 edition. Pearson, Essex, England. 